\title{
Ozonolysis of $\alpha$-pinene: parameterization of secondary organic aerosol mass fraction
}

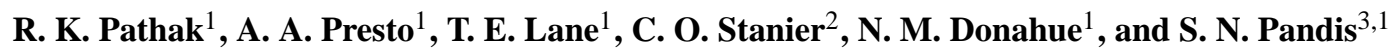 \\ ${ }^{1}$ Department of Chemical Engineering, Carnegie Mellon University, Pittsburgh, USA \\ ${ }^{2}$ Chemical \& Biochemical Engineering and IIHR Hydroscience and Engineering Department, Univ. of Iowa, Iowa City, USA \\ ${ }^{3}$ Department of Chemical Engineering, University of Patras, Patra, Greece
}

Received: 17 January 2007 - Published in Atmos. Chem. Phys. Discuss.: 7 February 2007

Revised: 6 June 2007 - Accepted: 21 June 2007 - Published: 24 July 2007

\begin{abstract}
Existing parameterizations tend to underpredict the $\alpha$-pinene aerosol mass fraction (AMF) or yield by a factor of 2-5 at low organic aerosol concentrations $\left(<5 \mu \mathrm{g} \mathrm{m}^{-3}\right)$. A wide range of smog chamber results obtained at various conditions (low/high $\mathrm{NO}_{\mathrm{x}}$, presence/absence of UV radiation, dry/humid conditions, and temperatures ranging from $15-40^{\circ} \mathrm{C}$ ) collected by various research teams during the last decade are used to derive new parameterizations of the SOA formation from $\alpha$-pinene ozonolysis. Parameterizations are developed by fitting experimental data to a basis set of saturation concentrations (from $10^{-2}$ to $10^{4} \mu \mathrm{g} \mathrm{m}^{-3}$ ) using an absorptive equilibrium partitioning model. Separate parameterizations for $\alpha$-pinene SOA mass fractions are developed for: 1) Low $\mathrm{NO}_{\mathrm{x}}$, dark, and dry conditions, 2) Low $\mathrm{NO}_{\mathrm{x}}$, $\mathrm{UV}$, and dry conditions, 3) Low $\mathrm{NO}_{\mathrm{x}}$, dark, and high $\mathrm{RH}$ conditions, 4) High $\mathrm{NO}_{\mathrm{x}}$, dark, and dry conditions, 5) High $\mathrm{NO}_{\mathrm{x}}, \mathrm{UV}$, and dry conditions. According to the proposed parameterizations the $\alpha$-pinene SOA mass fractions in an atmosphere with $5 \mu \mathrm{g} \mathrm{m}^{-3}$ of organic aerosol range from 0.032 to 0.1 for reacted $\alpha$-pinene concentrations in the $1 \mathrm{ppt}$ to $5 \mathrm{ppb}$ range.
\end{abstract}

\section{Introduction}

The annual global biogenic volatile organic carbon (VOC) flux is estimated to be $1150 \mathrm{TgC}$, composed of $44 \%$ isoprene, $11 \%$ monoterpenes, $22.5 \%$ other reactive VOC, and $22.5 \%$ other VOCs (Guenther et al., 1995; Griffin et al., 1999a). On a global scale, $\alpha$-pinene emissions are around $50 \mathrm{Tg} \mathrm{Cy}^{-1}$ (Guenther et al., 1995). Griffin et al. (1999a) estimated that $18.5 \mathrm{Tg}$ of SOA atmospheric secondary or-

Correspondence to: S. N. Pandis

(spyros@andrew.cmu.edu) ganic aerosol are formed annually from biogenic precursors, a number smaller than the previously published estimate of 30-270 Tg by Andreae and Crutzen (1997). Tsigaridis and Kanakidou (2003) argued that the global annual SOA production from biogenic VOC might range from 2.5 to $44.5 \mathrm{Tg}$. A number of recent studies (de Gouw et al., 2005; Heald et al., 2005; Volkamer et al., 2006; Takegawa et al., 2006) suggest that the SOA concentrations in both urban and urbaninfluenced more remote areas are underestimated by existing models.

Ozonolysis is one of the major $\alpha$-pinene oxidation pathways in the troposphere, contributing approximately $80 \%$ of the SOA from the $\alpha$-pinene degradation (Griffin et al., 1999a). Smog chamber studies show that the $\alpha$-pinene/O 3 reaction is quite efficient in forming SOA with aerosol mass fraction (AMF) as high as 0.67 for high $\alpha$-pinene concentrations (Hoffman et al., 1997). These studies suggest that the amount of reacted $\alpha$-pinene, ozone concentration, temperature, $\mathrm{NO}_{\mathrm{x}}$, UV light, relative humidity and the presence of other organic aerosol can affect the AMF.

In smog chamber experiments, the SOA mass fraction increases with increasing $\alpha$-pinene concentration (Odum et al., 1996; Hoffmann et al., 1997; Griffin et al., 1999b; Cocker et al., 2001; Hoppel et al., 2001; Pathak et al., 2007). Observed AMF trends can be explained by existing gas/particle partitioning models (Pankow 1994a, b; Odum et al., 1996; Pankow et al., 2001; Seinfeld et al., 2001; Seinfeld and Pankow, 2003).

Stanier et al. (2007) reported that the aerosol volume of $\alpha$-pinene SOA changes with temperature with concentrationtemperature dependences ranging from 0.6 to $2.9 \%$ per ${ }^{\circ} \mathrm{C}$. Pathak et al. (2007) reported a value of $1.6 \%$ per $^{\circ} \mathrm{C}$ (between 15 and $40^{\circ} \mathrm{C}$ ). A stronger temperature dependence of AMF on temperature (by a factor of 2) was observed between $0^{\circ} \mathrm{C}$ and $15^{\circ} \mathrm{C}$ (Pathak et al., 2007; Saathoff et al., 2004).

Published by Copernicus Publications on behalf of the European Geosciences Union. 


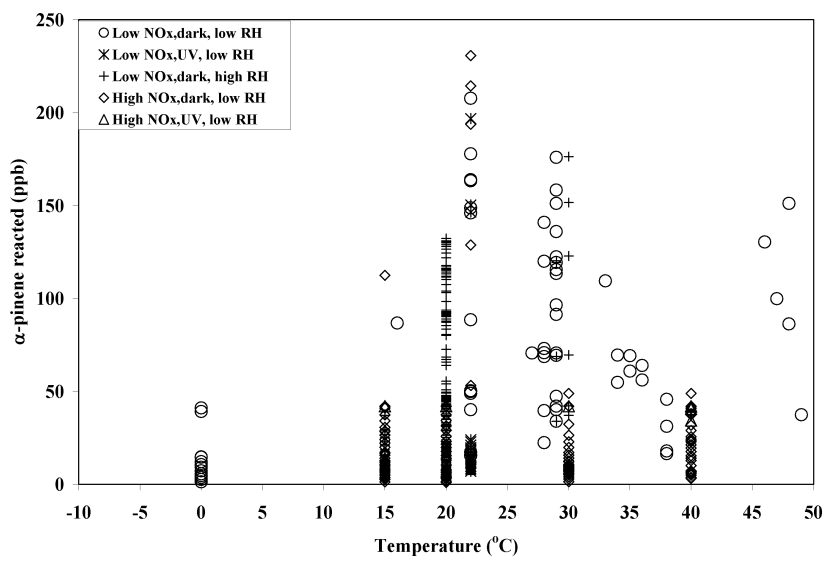

Fig. 1. Experimental data used to develop $\alpha$-pinene SOA AMF parameterizations plotted in the reacted $\alpha$-pinene versus temperature space. Different symbols are used for high/low $\mathrm{NO}_{\mathrm{x}}$, darkness or light and high/low RH.

SOA mass fraction decreases in the presence of both UV light and high concentrations of $\mathrm{NO}_{\mathrm{x}}$. SOA production is completely suppressed in some cases when both UV light and significant concentrations of $\mathrm{NO}_{\mathrm{x}}$ are present (Presto et al., 2005a, b). SOA formation may depend significantly on actinic flux, and the final products of ozonolysis depend on $\mathrm{NO}_{\mathrm{x}}$ concentration (usually expresses as $[\mathrm{VOC}] /\left[\mathrm{NO}_{\mathrm{x}}\right]$ ratio).

In the presence of water vapor, the distribution of SOA products from ozonolysis of $\alpha$-pinene and the corresponding AMF change (Jang and Kamens 1998; Fick et al., 2003). Jang and Kamens (1998) reported that the SOA formation was reduced in wet conditions (58-92\% RH) with no inorganic aerosol seeds. However, Cocker et al. (2001) found that the $\alpha$-pinene AMF varies little with RH in seed free conditions or in the presence of dry seeds, but the presence of aqueous salt seeds reduced the SOA mass fraction.

Several modules have been developed to predict SOA formation in atmosphere and are used in chemical transport models. The Odum/Griffin et al. (1999a) and Carnegie Mellon University/Sonoma Technology Inc. modules (Strader et al., 1999a, b) represent SOA absorptive partitioning into a mixture of primary and secondary particulate organic compounds, with some differences in the formulation of the absorption process, the selection of SOA species, and their precursors. Empirical representations based on measured laboratory AMF are used for condensable organic products in both these modules. The Atmospheric and Environmental Research (AER) module simulates SOA absorption into organic and aqueous particulate phases, and a representation based on an explicit gas-phase mechanism is used in the module developed by Pun et al. (2002). Pun et al. (2003) showed that these modules predicted SOA concentrations that can vary by a factor of 10 or more.
In general, smog chamber studies have been performed with excess of ozone and relatively high $\alpha$-pinene concentrations (>10 ppb). Chemical transport models use parameterizations extrapolating from these high concentration SOA AMFs (or equivalently at high organic aerosol loadings) to ambient conditions. Presto et al. (2006) argued that these extrapolations underestimate the SOA AMF by several factors for atmospherically relevant concentrations of $\alpha$-pinene $(<5 \mathrm{ppb}$ or atmospherically relevant organic aerosol levels $<10 \mu \mathrm{g} \mathrm{m}^{-3}$ ). Most published AMF parameterizations (e.g. Griffin et al., 1999b; Cocker et al., 2001) are derived by the empirical fits to the experimental data of a single investigator.

So far there exist no $\alpha$-pinene SOA parameterizations which have been developed and tested for low $\alpha$-pinene concentrations, low ozone, and variable levels of $\mathrm{UV}, \mathrm{NO}_{\mathrm{x}}, \mathrm{RH}$ and temperature. The development of such parameterizations requires collective treatment of smog chamber data from different series of experiments, enabling much wider coverage of the parameter space in terms of $\alpha$-pinene concentrations, temperature, $\mathrm{VOC} / \mathrm{NO}_{\mathrm{x}}, \mathrm{UV}$ and $\mathrm{RH}$.

In this paper, we use a wide range of SOA AMF measurements obtained at various conditions (low and high $\mathrm{NO}_{\mathrm{x}}$, dark and in the presence of UV light, dry and humid conditions, low and high temperatures) during the last decade from different chambers. We compliment these existing data with a few additional new measurements to cover gaps in the parameter space. We use the basis set of saturation vapor pressures in the range of $10^{-2}$ to $10^{4} \mu \mathrm{g} \mathrm{m}^{-3}$ (1.6 ppt-1.6 ppm for a molecular weight of $150 \mathrm{~g} \mathrm{~mol}^{-1}, 298 \mathrm{~K}$ and $\left.1 \mathrm{~atm}\right)$ to fit the measurements (Donahue et al., 2006). Different parameterizations are developed to fit the results at various experimental conditions. Finally, we propose a collection of AMF parameterizations, which could reproduce all the measurements made in previous smog chamber studies and can be used in chemical transport models.

\section{Experimental data for parameterization}

$\alpha$-pinene SOA AMFs measured by Hoffmann et al. (1997), Griffin et al. (1999b), Cocker et al. (2001), Winterhalter et al. (2003), Presto et al. (2005a, b, 2006), Ng et al. (2006), Lee et al. (2006) and Pathak et al. (2007) are used in this study. To cover gaps in the available data, we also performed additional experiments at high $\mathrm{NO}_{\mathrm{x}}$ at low $\mathrm{RH}$ in the dark, at high $\mathrm{NO}_{\mathrm{x}}$ in the presence of UV light at low $\mathrm{RH}$, and in low $\mathrm{NO}_{\mathrm{x}}$ at high $\mathrm{RH}$ in the dark. Dynamic AMFs were estimated from these experiments using real time data (Presto et al., 2006; Ng et al., 2006; Pathak et al., 2007). The dynamic AMF is the AMF measured continuously during an experiment, from the SOA produced and $\alpha$-pinene reacted at that point of time, while only a fraction of the initial $\alpha$-pinene has reacted. The final AMF is the AMF estimated at the end of experiment, when all of the $\alpha$-pinene has reacted. The AMF is used throughout this paper instead of the equivalent 
Table 1. Summary of $\alpha$-pinene AMF measurements used in this study.

\begin{tabular}{|c|c|c|c|c|}
\hline $\begin{array}{l}\text { Experimental } \\
\text { Conditions }\end{array}$ & Study & $\begin{array}{l}\text { Number of } \\
\text { Experiments } \\
\text { ( Data points) }\end{array}$ & $\begin{array}{l}\alpha \text {-pinene Concentra- } \\
\text { tion Range (ppb) }\end{array}$ & $\begin{array}{l}\text { Temperature Range } \\
\left({ }^{\circ} \mathrm{C}\right)\end{array}$ \\
\hline \multirow{3}{*}{$\begin{array}{l}\text { High } \mathrm{NO}_{\mathrm{x}} \text {, dark, } \\
\text { and low } \mathrm{RH}(<10 \%)\end{array}$} & Presto et al. (2005 b) & $6(6)$ & $16-214$ & 22 \\
\hline & Presto et al. (2006) & $1(9)$ & $9-11$ & 22 \\
\hline & This study $^{\mathrm{a}}$ & $1(13)$ & $28-42$ & $15-40$ \\
\hline \multirow{2}{*}{$\begin{array}{l}\text { High } \mathrm{NO}_{\mathrm{x}}, \mathrm{UV}, \\
\text { and low } \mathrm{RH}(<10 \%)\end{array}$} & Presto et al. (2006) & $1(13)$ & $7.5-11$ & 22 \\
\hline & This study ${ }^{a}$ & $1(16)$ & $34-42$ & $15-40$ \\
\hline \multirow{10}{*}{$\begin{array}{l}\text { Low } \mathrm{NO}_{\mathrm{x}} \text {, dark, } \\
\text { and low } \mathrm{RH}(<10 \%)\end{array}$} & Cocker et al. (2001) & $24(24)$ & $22-175$ & $28-30$ \\
\hline & Griffin et al. (1999b) & $6(6)$ & $18-63$ & $35-37$ \\
\hline & Hoffmann et al. (1997) & $6(6)$ & $37-151$ & $16-49$ \\
\hline & Lee et al. (2006) & $1(1)$ & 175 & 19 \\
\hline & $\mathrm{Ng}$ et al. (2006) & $1(51)$ & 178 & 20 \\
\hline & Pathak et al. (2006) & $41(114)$ & $1-50$ & $0-40$ \\
\hline & Presto et al. (2005a) & $14(14)$ & $15-207$ & 22 \\
\hline & Presto et al. (2006) & $4(4)$ & $13-133$ & 22 \\
\hline & Winterhalter et al. (2003) & $2(2)$ & $55-70$ & 35 \\
\hline & Yu et al. (1999) & $3(3)$ & $45-65$ & 35 \\
\hline \multirow{2}{*}{$\begin{array}{l}\text { Low } \mathrm{NO}_{\mathrm{X}}, \mathrm{UV} \text {, } \\
\text { and low RH }(<10 \%)\end{array}$} & Presto et al. (2005a) & $6(6)$ & $8-196$ & 22 \\
\hline & Presto et al. (2006) & $1(12)$ & $7-24$ & 22 \\
\hline \multirow{4}{*}{$\begin{array}{l}\text { Low } \mathrm{NO}_{\mathrm{x}} \text {, dark, } \\
\text { and high } \mathrm{RH} \\
(50-73 \%)\end{array}$} & Gao et al. (2004) & $7(177)$ & $1-132$ & 20 \\
\hline & $\mathrm{Ng}$ et al. (2006) & $7(177)$ & $1-132$ & 20 \\
\hline & Cocker et al. (2001) & $9(9)$ & $42-176$ & $28-30$ \\
\hline & This study $\mathrm{b}$ & $1(16)$ & $5-37$ & $15-40$ \\
\hline
\end{tabular}

a The $\alpha$-pinene ozonolysis took place at $40^{\circ} \mathrm{C}$. After completion of the reaction, the smog chamber temperature was changed to $30^{\circ} \mathrm{C}, 20^{\circ} \mathrm{C}$ and $15^{\circ} \mathrm{C}$.

b The $\alpha$-pinene ozonolysis took place at $15^{\circ} \mathrm{C}$. After completion of the reaction, the smog chamber temperature was changed to $20^{\circ} \mathrm{C}, 30^{\circ} \mathrm{C}$ and $40^{\circ} \mathrm{C}$.

but rather confusing "aerosol yield" that has been used in previous studies (Odum et al., 1996). The normalized AMF assumes a density of $1 \mathrm{~g} \mathrm{~cm}^{-3}$ for the SOA and should be multiplied with the actual density to calculate the AMF.

$\mathrm{Ng}$ et al. (2006) and Cocker et al. (2001) performed some of their experiments in high $\mathrm{RH}$ conditions (55-65\%) and their results are used to parameterize the RH effects on the $\alpha$ pinene AMF. Presto et al. (2005a, b) investigated the effects of high $\mathrm{NO}_{\mathrm{x}}$ in presence of UV light at $22^{\circ} \mathrm{C}$. Additional experiments are reported here to obtain the temperature dependence of these effects. Pathak et al. (2007) performed $\alpha$-pinene ozonolysis experiments in the dark at a range of temperatures from $0^{\circ} \mathrm{C}$ to $40^{\circ} \mathrm{C}$. In this study, both the final and dynamic AMFs from some of the above-mentioned studies are used to develop the $\alpha$-pinene SOA parameterizations.

An overview of the available $\alpha$-pinene ozonolysis experiments plotted in the temperature-precursor concentration space is shown in Fig. 1. Table 1 provides a summary of the various data sources and their experimental conditions. The available measurements together with the results of proposed parameterizations are shown in Fig. 2. A number of

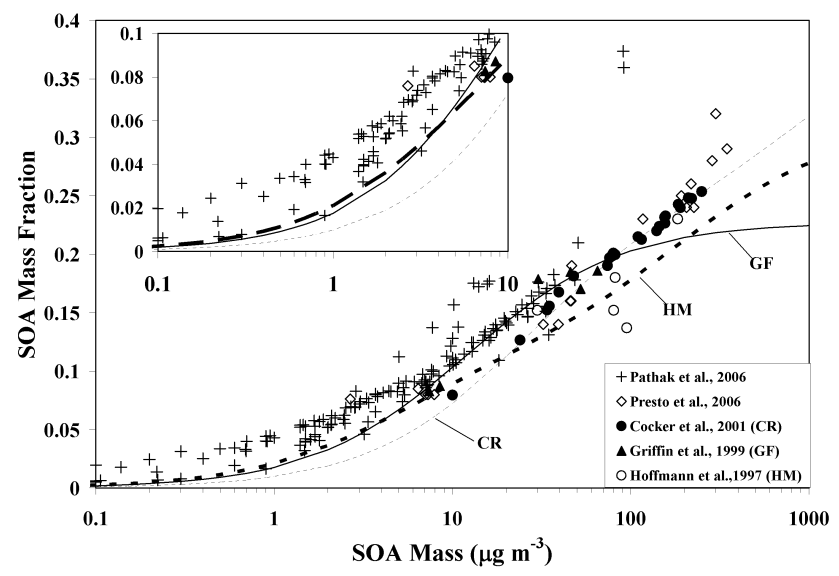

Fig. 2. SOA AMF as function of SOA mass. Comparison of measurements in various smog chamber studies and predictions by the existing 2-products parameterizations. The Hoffmann et al. (1997), Griffin et al. (1999), and Cocker et al. (2001) parameterizations are denoted by HM, GF and CR, respectively. The experimental conditions for all studies can be found in Table 1 . 
Table 2. Summary of $\alpha$-pinene experiments in this study.

\begin{tabular}{cccccccl}
\hline Exp. No. & $\begin{array}{c}\alpha \text {-pinene } \\
(\mathrm{ppb})\end{array}$ & $\begin{array}{c}\text { Ozone } \\
(\mathrm{ppb})\end{array}$ & $\begin{array}{c}\text { Temp } \\
\left({ }^{\circ} \mathrm{C}\right)\end{array}$ & $\begin{array}{c}\text { Seed } \\
\left(\mathrm{cm}^{-3}\right)\end{array}$ & $\begin{array}{c}\text { SOA Mass } \\
\left(\mu \mathrm{g} / \mathrm{m}^{3}\right)\end{array}$ & AMF & $\begin{array}{l}\text { Experimental } \\
\text { Conditions }\end{array}$ \\
\hline $1^{\mathrm{a}}$ & 38 & 250 & 15 & 6700 & 45.97 & 0.21 & $\begin{array}{l}63-73 \% \mathrm{RH}, \\
\text { dark, } \mathrm{NO}_{\mathrm{x}}<3 \mathrm{ppb}\end{array}$ \\
$2^{\mathrm{b}}$ & 42 & 250 & 40 & 8300 & 5.65 & 0.025 & $\begin{array}{l}220 \mathrm{ppb} \mathrm{NO}_{2}, \\
\text { dark, } \mathrm{RH}_{10} \%\end{array}$ \\
$3^{\mathrm{b}}$ & 42 & 370 & 40 & 8200 & 5.33 & 0.023 & $\begin{array}{l}210 \mathrm{ppb} \mathrm{NO}_{2}, \\
\text { UV lights, } \mathrm{RH}<10 \%\end{array}$ \\
\hline
\end{tabular}

\footnotetext{
a The $\alpha$-pinene ozonolysis reaction was performed at $15^{\circ} \mathrm{C}$. After the completion of reaction temperature was changed to $20^{\circ} \mathrm{C}, 30^{\circ} \mathrm{C}$ and $40^{\circ} \mathrm{C}$ and AMFs were estimated. The RH was around $65 \%$ at $15^{\circ} \mathrm{C}$ and it decreased to $20 \%$ when temperature was increased to $40^{\circ} \mathrm{C}$.

$\mathrm{b}$ The $\alpha$-pinene ozonolysis reaction was performed at $40^{\circ} \mathrm{C}$. After completion of the reaction, the smog chamber temperature was changed to $30^{\circ} \mathrm{C}, 20^{\circ} \mathrm{C}$ and $15^{\circ} \mathrm{C}$.
}

studies with either incomplete published datasets for use in the parameterization (Fick et al., 2003; Jang et al., 1998) or for different experimental conditions (Iinuma et al., 2004; Czoschke and Jang, 2006) were not used in the present study.

Based on the collective information on secondary organic AMFs from $\alpha$-pinene ozonolysis at different conditions five parameterizations covering the following parts of the condition space will be developed:

- Low $\mathrm{NO}_{\mathrm{x}}$ with variable temperature, low $\mathrm{RH}$, dark

- High $\mathrm{NO}_{\mathrm{x}}$ with variable temperature, low $\mathrm{RH}$, dark

- UV effects on AMF with variable temperature, low RH, low $\mathrm{NO}_{\mathrm{x}}$

- UV effects on AMF with variable temperature, low RH, high $\mathrm{NO}_{\mathrm{x}}$

- High RH, low $\mathrm{NO}_{\mathrm{x}}$, dark

For the purposes of this study we assume that $\mathrm{VOC} / \mathrm{NO}_{\mathrm{x}}>10 \mathrm{ppbC} / \mathrm{ppb}$ in the low $\mathrm{NO}_{\mathrm{x}}$ regime and that $\mathrm{VOC} / \mathrm{NO}_{\mathrm{x}}<3 \mathrm{ppbC} / \mathrm{ppb}$ in the high $\mathrm{NO}_{\mathrm{x}}$ regime.

\subsection{Experimental method}

Experimental methods are only discussed for the experimental results not reported elsewhere. Three experiments were performed in the Carnegie Mellon University smog chamber using a $10 \mathrm{~m}^{3}$ Teflon reactor (Welch Fluorocarbons). The experiments were conducted at constant temperatures $\left(15^{\circ} \mathrm{C}\right.$ or $40^{\circ} \mathrm{C}$ ). Each constant temperature experiment was followed by a temperature ramp to investigate temperature-dependent partitioning. Experiments were carried out at initial $\alpha$-pinene concentrations of $38 \pm 1.5 \mathrm{ppb}$. In the low $\mathrm{NO}_{\mathrm{x}}$ experiments, $\mathrm{NO}_{\mathrm{x}}$ concentrations in the bag were less than a few ppb. In the high $\mathrm{NO}_{\mathrm{x}}$ experiments, the VOC carbon to $\mathrm{NO}_{\mathrm{x}}$ concentration ratio was approximately 10 . In the high $\mathrm{RH}$ experiment, the measured $\mathrm{RH}$ was around $65 \%$ at $15^{\circ} \mathrm{C}$. However, as temperature was changed it dropped to approximately $25 \%$ at $40^{\circ} \mathrm{C}$. Water vapor was added to the reactor during the experiment to avoid an even larger change in $\mathrm{RH}$.

The experiments were carried out with an excess of ozone produced from an ozone generator (Azco HTU500ACPS). Reactions were carried out in the presence of an $\mathrm{OH}-$ scavenger (2-butanol) in excess $(0.5 \mathrm{ml}$, which is $500-2000$ times the initial $\alpha$-pinene concentration). All experiments were performed in the presence of polydisperse seed aerosols generated from $7 \mathrm{mM}(0.9 \mathrm{~g} / \mathrm{L})$ ammonium sulfate aqueous solutions. The seed aerosol concentrations were usually between 4000-6000 particle $\mathrm{cm}^{-3}$. The particle density of SOA was assumed to be $1 \mathrm{~g} \mathrm{~cm}^{-3}$ for all calculations in the paper (normalized AMF). The instrumentation, reagents used, wall loss correction, and AMF calculation details have been described by are Pathak et al. (2007). A summary of the results of these experiments is provided in Table 2.

\subsection{Low $\mathrm{NO}_{\mathrm{x}}$, dark and low $\mathrm{RH}$ AMF}

In these experiments, SOA formation during the $\alpha$-pinene reaction with $\mathrm{O}_{3}$ has been studied in the dark with very low $\mathrm{NO}_{\mathrm{x}}$ concentrations in the temperature range between $0^{\circ} \mathrm{C}$ and $49^{\circ} \mathrm{C}$ at low RH $(<10 \%)$ (Hoffmann et al., 1997; Griffin et al., 1999b; Yu et al., 1999; Cocker et al., 2001; Winterhalter et al., 2003; Presto et al., 2005a, 2006; Ng et al., 2006; Lee et al., 2006; Pathak et al., 2007). Measured $\alpha$-pinene SOA AMFs have ranged from 0.005 to 0.45 depending on the amount of $\alpha$-pinene reacted and temperature. For example, for reacted $\alpha$-pinene concentrations from 1 to $40 \mathrm{ppb}$, the corresponding AMF ranged from 0.02 to 0.21 at $20^{\circ} \mathrm{C}$. The AMF increases at lower temperatures (Pathak et al., 2007).

\subsection{High $\mathrm{NO}_{\mathrm{x}}$, dark and low RH AMF}

The SOA mass fraction in the $\alpha$-pinene $/ \mathrm{O}_{3} / \mathrm{NO}_{\mathrm{x}}$ reaction system changes quite dramatically with increasing $\mathrm{NO}_{\mathrm{x}}$. This change in AMFs is partially due to the formation of organic 
nitrate compounds with higher vapor pressure, which preferentially remain in the gas phase (Zhang et al., 2007). Presto et al. (2005b) investigated the SOA formation during the apinene ozonolysis at $22^{\circ} \mathrm{C}$ and low $\mathrm{RH}$ with variable $\mathrm{NO}_{\mathrm{x}}$ concentrations. These authors performed their high $\mathrm{NO}_{\mathrm{x}}$ experiments at $[\mathrm{VOC}]_{o} /\left[\mathrm{NO}_{\mathrm{x}}\right]_{o}(\mathrm{ppbC} / \mathrm{ppb})$ ratios of $1-2$. Their results are used for the development of the parameterization for the high $\mathrm{NO}_{\mathrm{x}}$ regime defined here as $[\mathrm{VOC}]_{o} /\left[\mathrm{NO}_{\mathrm{x}}\right]_{o}$ $(\mathrm{ppbC} / \mathrm{ppb})<10$ (Presto et al., 2005b). These authors argued that $\mathrm{NO}_{3}$ was at most a secondary contributor to the observed chemistry (it contributed less than $20 \%$ to the $\alpha$-pinene removal) in their experiment.

In the present study, an additional experiment was performed for a $[\mathrm{VOC}]_{o} /\left[\mathrm{NO}_{\mathrm{x}}\right]_{o}(\mathrm{ppbC} / \mathrm{ppb})$ ratio of about 2 at $40^{\circ} \mathrm{C}$ (Table 2). The final SOA mass fraction was 0.025 for $42 \mathrm{ppb}$ reacted $\alpha$-pinene. The temperature of the chamber was then reduced and we measured AMFs at 30,20 and $15^{\circ} \mathrm{C}$ equal to $0.053,0.066$, and 0.067 , respectively. This change corresponds to an effective heat of vaporization of approximately $30 \mathrm{~kJ} \mathrm{~mol}^{-1}$, a value consistent with the $33 \mathrm{~kJ} \mathrm{~mol}^{-1}$ measured by Offenburg et al. (2006) at high $\mathrm{NO}_{\mathrm{x}}$ conditions

\subsection{UV effect on AMF in low and high $\mathrm{NO}_{\mathrm{x}}$ conditions}

Presto et al. (2005a) measured the SOA concentrations formed from the $\alpha$-pinene $/ \mathrm{O}_{3}$ reaction with the chamber UV lights turned on with variable $\mathrm{NO}_{\mathrm{x}}$ concentrations (from low to high $[\mathrm{VOC}]_{o} /\left[\mathrm{NO}_{\mathrm{x}}\right]_{o}$ ratio: 0.5 to 100 ) at $22^{\circ} \mathrm{C}$ and low RH. The SOA AMF decreased in the presence of UV light. The AMFs decreased almost by a constant fraction of 0.03 irrespective of the amount of $\alpha$-pinene reacted in the low $\mathrm{NO}_{\mathrm{x}}$ regime. No SOA was formed for reacted $\alpha$-pinene concentration less than $6 \mathrm{ppb}$ in this low $\mathrm{NO}_{\mathrm{x}}$ case. The effect of UV was similar in the high $\mathrm{NO}_{\mathrm{x}}$ case resulting in reduced AMFs. For example, for $10 \mathrm{ppb}$ of reacted $\alpha$-pinene, the measured AMF in the high $\mathrm{NO}_{\mathrm{x}}$ regime decreased from 0.01 (dark) to 0.0035 (UV lights).

In this study, an additional experiment was performed in the high $\mathrm{NO}_{\mathrm{x}}$ regime at $40^{\circ} \mathrm{C}$, and the SOA concentration was measured at different temperatures $\left(15^{\circ} \mathrm{C}, 20^{\circ} \mathrm{C}\right.$ and $30^{\circ} \mathrm{C}$ ) after the completion of the reaction.

\subsection{AMF for high $\mathrm{RH}$ and low $\mathrm{NO}_{\mathrm{x}}$ in the dark}

Cocker et al. (2001), Gao et al. (2004) and Ng et al. (2006) and have reported AMFs for this system at $50-65 \% \mathrm{RH}$, under low $\mathrm{NO}_{\mathrm{x}}$ conditions in the dark in the $20-30^{\circ} \mathrm{C}$ temperature range (Table 1). One additional experiment was performed in this study at $65 \% \mathrm{RH}$ at $15^{\circ} \mathrm{C}$ and after the completion of the ozonolysis reaction the SOA concentration was measured at $20^{\circ} \mathrm{C}, 30^{\circ} \mathrm{C}$ and $40^{\circ} \mathrm{C}$.

The AMFs that have measured in the high RH regime exceed those that have measured at dry conditions by a factor of 1.5 or so. Under high RH conditions, the $\alpha$-pinene SOA concentration shows a rather strong temperature dependence

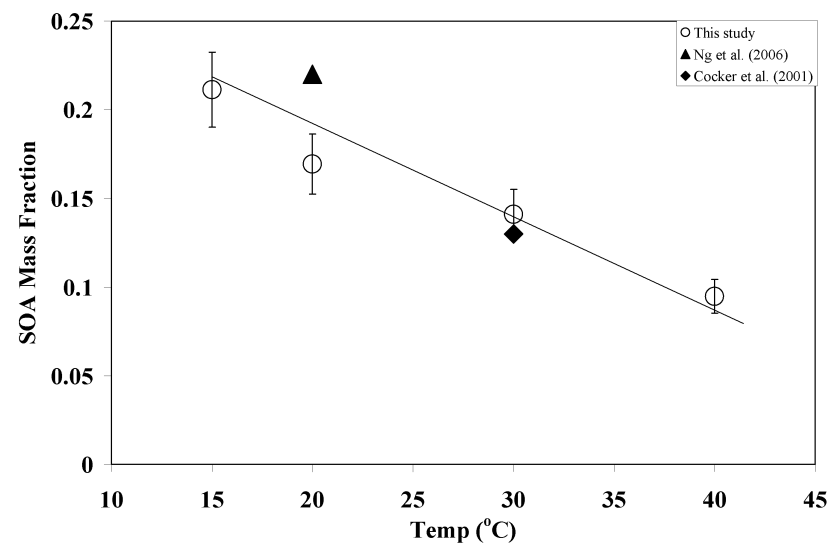

Fig. 3. SOA mass fraction as a function of temperature for reacted a-pinene concentrations around $35 \mathrm{ppb}$. For this study the reaction was carried out at $15^{\circ} \mathrm{C}$ and then temperature was increased to 20 , 30 and $40^{\circ} \mathrm{C}$. The initial $\mathrm{RH}$ of our experiment at $15^{\circ} \mathrm{C}$ was $65 \%$, while the final $\mathrm{RH}$ at $40^{\circ} \mathrm{C}$ was $25 \%$. The $\mathrm{Ng}$ et al. (2006) measurements were at $55 \%$, while the Cocker et al. (2001) measurements were at $50 \%$.

(Fig. 3), with the AMFs decreasing almost by a factor of 2 as temperature increased from $15^{\circ} \mathrm{C}$ to $30^{\circ} \mathrm{C}$. The water content of the a-pinene SOA when the RH is less than $65 \%$ is less than $20 \%$ (Koo et al., 2003) therefore it plays a relatively small role in the measured changes of the AMF with increasing temperature. The relatively good agreement of the results of the experiments where the reaction took place at a $20^{\circ} \mathrm{C}$ and $30^{\circ} \mathrm{C}$ respectively, with the results of our study (the reaction took place at $15^{\circ} \mathrm{C}$ and then the chamber was heated to $20^{\circ} \mathrm{C}$ and $30^{\circ} \mathrm{C}$ ) suggests that the change in the partitioning of the SOA products dominates the measured changes of the AMF with temperature. The potential changes in the yields of the different products at different temperatures and the changes in aerosol water content appear to play a secondary role.

\section{AMF parameterization}

A major challenge in modeling SOA partitioning behavior is the complexity of multi-component aerosol mixture, which contains tens or even hundreds of individual components, each with its unique partitioning properties. A practical approach is to approximate the detailed SOA mixture with a few surrogate compounds. The surrogate compounds are not real, but simply a numerical representation of the actual aerosol components.

Most SOA AMF parameterizations have been derived from empirical fits of experimental data using two surrogate products (Odum et al., 1996). In these parameterizations, essentially, one product represents more volatile compounds while the other describes the low volatility products (Odum et al., 1996; Hoffmann et al., 1997; Griffin et al., 1999b; 
Table 3. Summary of parameterizations and their evaluation.

\begin{tabular}{|c|c|c|c|c|c|c|c|c|c|c|c|c|c|c|c|c|c|}
\hline \multirow{4}{*}{$\begin{array}{l}\begin{array}{l}\text { Experimental Conditions } \\
\text { and Parameterizations }\end{array} \\
\text { Low } \mathrm{NO}_{\mathrm{x}} \text {, dark, } \\
\text { low } \mathrm{RH} \text { (this study) }\end{array}$} & \multirow{3}{*}{$\begin{array}{c}\begin{array}{c}\text { Number of } \\
\text { products }\end{array} \\
7\end{array}$} & \multicolumn{7}{|c|}{$\mathrm{c}^{\circ}$ values $\left(\mu \mathrm{g} \mathrm{m}^{3}\right)$} & \multicolumn{7}{|c|}{$\alpha$ (Stoichiometric Coefficients) values } & \multirow{3}{*}{$\begin{array}{c}\begin{array}{c}\Delta H_{\text {evap }} \\
\left(\mathrm{kJ} \mathrm{mol}^{-1}\right)\end{array} \\
30\end{array}$} & \multirow{4}{*}{$\begin{array}{c}\text { Relative } \\
\text { Errors (\%) } \\
16 \\
15\end{array}$} \\
\hline & & \multirow{2}{*}{$\begin{array}{c}\mathrm{C}_{1}^{o} \\
0.01\end{array}$} & \multirow{2}{*}{$\begin{array}{l}\mathrm{C}_{2}^{o} \\
0.1\end{array}$} & \multirow{2}{*}{$\begin{array}{c}\mathrm{C}_{3}^{o} \\
1\end{array}$} & \multirow{2}{*}{$\begin{array}{l}\mathrm{C}_{4}^{o} \\
10\end{array}$} & \multirow{3}{*}{$\begin{array}{c}\mathrm{C}_{5}^{o} \\
100\end{array}$} & \multirow{3}{*}{$\begin{array}{c}\mathrm{C}_{6}^{o} \\
1000\end{array}$} & \multirow{3}{*}{$\begin{array}{c}\mathrm{C}_{7}^{o} \\
10000\end{array}$} & \multirow{2}{*}{$\begin{array}{c}\alpha_{1} \\
0.001\end{array}$} & \multirow{2}{*}{$\begin{array}{c}\alpha_{2} \\
0.012\end{array}$} & \multirow{2}{*}{$\begin{array}{c}\alpha_{3} \\
0.037\end{array}$} & \multirow{2}{*}{$\begin{array}{c}\alpha_{4} \\
0.088\end{array}$} & \multirow{3}{*}{$\begin{array}{c}\alpha_{5} \\
0.099\end{array}$} & \multirow{3}{*}{$\begin{array}{c}\alpha_{6} \\
0.250\end{array}$} & \multirow{3}{*}{$\begin{array}{c}\alpha_{7} \\
0.800\end{array}$} & & \\
\hline & & & & & & & & & & & & & & & & & \\
\hline & 4 & 1 & 10 & 100 & 1000 & & & & 0.070 & 0.038 & 0.179 & 0.300 & & & & 30 & \\
\hline \multirow{2}{*}{$\begin{array}{l}\text { High } \mathrm{NO}_{\mathrm{x}} \text {, dark, } \\
\text { low RH (this study) }\end{array}$} & 7 & 0.01 & 0.1 & 1 & 10 & 100 & 1000 & 10000 & 0.000 & 0.002 & 0.003 & 0.065 & 0.080 & 0.250 & 0.800 & 30 & 16 \\
\hline & 4 & 1 & 10 & 100 & 1000 & & & & 0.008 & 0.050 & 0.100 & 0.250 & & & & 30 & 16 \\
\hline \multirow{2}{*}{$\begin{array}{l}\text { High } \mathrm{NO}_{\mathrm{x}}, \mathrm{UV}, \\
\text { low RH (this study) }\end{array}$} & 7 & 0.01 & 0.1 & 1 & 10 & 100 & 1000 & 10000 & 0.0 & 0.001 & 0.001 & .06 & .075 & 0.245 & 0.795 & 30 & 17 \\
\hline & 4 & 1 & 10 & 100 & 1000 & & & & 0.005 & 0.05 & 0.1 & 0.25 & & & & 30 & 17 \\
\hline \multirow{2}{*}{$\begin{array}{l}\text { Low } \mathrm{NO}_{\mathrm{x}} \text {, dark, } \\
\text { high } \mathrm{RH} \text { (this study) }\end{array}$} & 7 & 0.01 & 0.1 & 1 & 10 & 100 & 1000 & 10000 & 0.001 & 0.012 & 0.04 & 0.07 & 0.15 & 0.35 & 0.700 & 70 & 16 \\
\hline & 4 & 1 & 10 & 100 & 1000 & & & & 0.035 & 0.099 & 0.162 & 0.384 & & & & 70 & 17 \\
\hline \multirow{2}{*}{$\begin{array}{l}\text { Low } \mathrm{NO}_{\mathrm{x}}, \mathrm{UV}, \\
\text { low RH (this study) }\end{array}$} & 7 & 0.01 & 0.1 & 1 & 10 & 100 & 1000 & 10000 & 0.000 & 0.000 & 0.024 & 0.078 & 0.060 & 0.222 & 0.770 & 30 & 9 \\
\hline & 4 & 1 & 10 & 100 & 1000 & & & & 0.024 & 0.078 & 0.080 & 0.300 & & & & 30 & 9 \\
\hline $\begin{array}{l}\text { Low } \mathrm{NO}_{\mathrm{x}}, \text { dark, } \\
\text { low } \mathrm{RH} \\
\text { (Hoffman et al., 1997) }\end{array}$ & 2 & 5 & 200 & & & & & & 0.12 & 0.19 & & & & & & $30^{*}$ & 17 \\
\hline $\begin{array}{l}\text { Low } \mathrm{NO}_{\mathrm{x}} \text {, dark, } \\
\text { low RH } \\
\text { (Griffin et al., } 1999 \text { ) }\end{array}$ & 2 & 11.4 & 12.7 & & & & & & 0.125 & 0.102 & & & & & & $30 *$ & 24 \\
\hline $\begin{array}{l}\text { Low } \mathrm{NO}_{\mathrm{x}} \text {, dark, low RH } \\
\text { (Cocker et al., 2001) }\end{array}$ & 2 & 23.8 & 1000 & & & & & & 0.239 & 0.169 & & & & & & $30^{*}$ & 33 \\
\hline
\end{tabular}

* $\Delta H_{\text {evap }}$ of $30 \mathrm{~kJ} \mathrm{~mol}^{-1}$ is used to predict AMFs at different temperatures. This value was not part of the original parameterizations.

Cocker et al., 2001). Saturation concentration $\left(c^{o}\right)$ and stoichiometric coefficients $(\alpha)$ for the $\alpha$-pinene AMF provided by Hoffmann et al. (1997), Griffin et al. (1999b) and Cocker et al. (2001) are listed in Table 3. For simplicity, Hoffmann et al. (1997), Griffin et al. (1999b) and Cocker et al. (2001) parameterizations are denoted as $\mathrm{HM}, \mathrm{GF}$ and $\mathrm{CR}$, respectively, in the rest of the paper. Each of these parameterizations was derived from the measured AMF at one temperature (or a very narrow range of temperatures) for relatively high $\alpha$-pinene concentrations. The HM parameterization was derived from the AMFs for higher $\alpha$-pinene concentrations $(88-154 \mathrm{ppb})$ at higher temperature $\left(48^{\circ} \mathrm{C}\right)$, and in experiments without an $\mathrm{OH}$ radical scavenger. The GF parameterization was derived from data at lower $\alpha$-pinene concentrations $(15-65 \mathrm{ppb})$, lower temperature $\left(32-37^{\circ} \mathrm{C}\right)$ and in presence of 2-butanol as $\mathrm{OH}$ scavenger. The $\mathrm{CR}$ parameterization was developed from a range of $\alpha$-pinene concentrations (23-163 ppb), almost covering the range of both HM and GR parameterizations, in the presence of an $\mathrm{OH}$ scavenger (2butanol), at the lowest temperature $\left(28-30^{\circ} \mathrm{C}\right)$ among them. As a result of the above differences in conditions, their parameters $\left(c_{i}^{o}\right.$ and $\left.\alpha_{i}\right)$ differ significantly (Table 3 ). As discussed by Presto and Donahue (2006), the measured dynamic AMFs at low organic aerosol mass concentrations $\left(<5 \mu \mathrm{g} \mathrm{m}^{-3}\right)$ are higher than the AMFs predicted by these older parameterizations by a factor of 2-5 (Fig. 2). These differences illustrate the difficulty in extrapolating from high to low concentrations and support the need for new parame- terizations, which can reproduce both the old and new measurements.

\subsection{Multiple products-basis set approach}

Donahue et al. (2006) proposed the use of a basis set of surrogate compounds (predetermined rather than fitted saturation concentrations) rather than the procedure common in previous published parameterizations of using fitted yields and fitted saturation concentrations. The lower and upper ends of the volatility range too are selected to cover the range of atmospheric conditions and to keep the parameterization error below a threshold. The selection of the saturation concentrations is predetermined using a fixed basis set (lognormally spaced from 0.01 to $10^{5} \mu \mathrm{g} \mathrm{m}^{-3}$ ) and stoichiometric coefficients $\left(\alpha_{i}\right)$ are fit to reproduce the measured AMFs. In this study we will be using the fixed saturation concentration from the 4- and 7-products basis sets to develop the new $\alpha$ pinene AMF parameterizations. In this basis-set formulation the stoichiometric coefficients $\left(\alpha_{i}\right)$ are assumed to be temperature independent over the temperature range of applicability of the parameterization.

The fitting problem is formulated in terms of $m$ smog chamber experiments, each with an $\mathrm{AMF} Y_{j}$, temperature $T_{j}$, and consumed reactant concentration $\Delta \mathrm{ROG}_{j}$. The most general model uses $n$ surrogate components defined by their stoichiometric yield vector $(\boldsymbol{\alpha})$, saturation concentration vector $\left(\boldsymbol{c}^{\boldsymbol{o}}\right)$, molecular weight vector $(\boldsymbol{M})$ and enthalpy of vapor- 

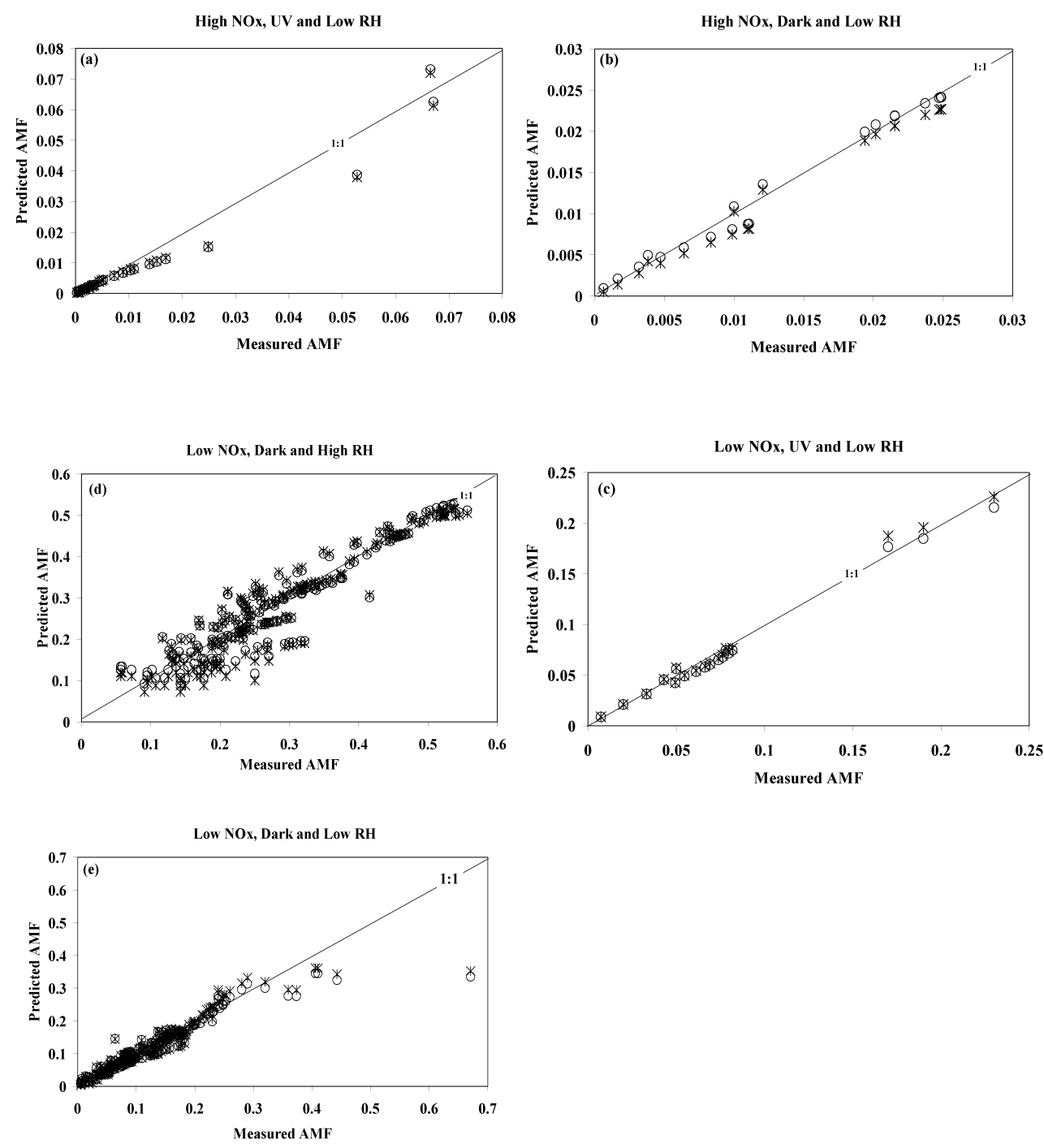

Fig. 4. Comparison of measured and predicted AMFs by 7 product (circles) and 4 product (asterisks) parameterizations in this study for: (a) high $\mathrm{NO}_{\mathrm{x}}, \mathrm{UV}$, and low $\mathrm{RH}$, (b) high $\mathrm{NO}_{\mathrm{x}}$, dark, and low $\mathrm{RH}$, (c) low $\mathrm{NO}_{\mathrm{x}}, \mathrm{UV}$, and low $\mathrm{RH}$, (d) low $\mathrm{NO}_{\mathrm{x}}$, dark, and high $\mathrm{RH}$ and (e) low $\mathrm{NO}_{\mathrm{X}}$, dark, and low RH.

ization vector $\left(\boldsymbol{\Delta} \boldsymbol{H}_{\text {evap }}\right)$. In the general case, the predicted AMF depends on:

$Y_{j, \text { fitted }}=f\left(\Delta \mathrm{ROG}_{j}, T_{j}, \boldsymbol{\alpha}, \boldsymbol{c}^{\boldsymbol{o}}, \boldsymbol{M}, \boldsymbol{\Delta} \boldsymbol{H}_{\mathrm{evap}}\right)$

An enthalpy of vaporization ( $\Delta H_{\text {evap }}$ ), the same for the entire basis set, is selected so that the temperature dependence of AMF values matches that seen in the Carnegie Mellon chamber (Stanier et al., 2007; Pathak et al., 2007). The error introduced by the use of a single $\Delta H_{\text {evap }}$ value and temperatureindependent stoichiometric coefficients can be estimated by comparing the fitted results at different temperatures with the measurements. The $\Delta H_{\text {evap }}$ used here should be viewed as an "effective" enthalpy of vaporization accounting for the various temperature effects on the AMF. In this work, the reference temperature $\left(T_{\text {ref }}\right)$ for the basis set saturation con- centrations is $298 \mathrm{~K}$ and the values for molecular weights of organic aerosol are assumed to be $150 \mathrm{~g} \mathrm{~mol}^{-1}$. The sum of the square errors

$\sum_{j=1,2 \ldots m}\left(Y_{j, \text { measured }}-Y_{j, \text { fitted }}\right)^{2}$

is minimized to determine the vector with the stoichiometric coefficients $\left(\alpha_{i}\right)$. For some experiments where the SOA yield was measured as a function of time, multiple values were used in the fitting.

\subsection{Collective parameterizations for $\alpha$-pinene/ozone SOA mass fraction}

The $\alpha$-pinene SOA mass fraction depends on multiple variables (temperature, $\mathrm{RH}, \mathrm{NO}_{\mathrm{x}}$, etc.), as described in previous 


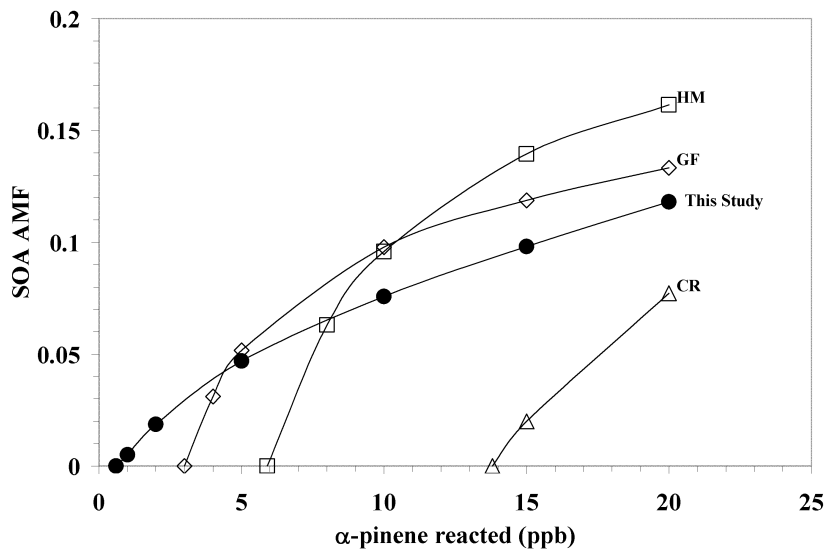

Fig. 5. Predicted SOA AMF by this study (7 product basis set) and existing parameterizations as a function of $\alpha$-pinene reacted in low $\mathrm{NO}_{\mathrm{x}}$, dark and low RH conditions at $298 \mathrm{~K}$.

sections. It is always desirable to synthesize a single parameterization, which can reproduce all the measurements. However, as the environmental variables change the distribution of the products or chemistry of SOA formation changes, e.g. in high $\mathrm{NO}_{\mathrm{x}}$ conditions more volatile products are formed compared to low $\mathrm{NO}_{\mathrm{x}}$. Therefore, development of a single super-parameterization may not be possible with the available set of measurements. Nevertheless, a collection of parameterizations for various conditions of SOA formation can be developed. To achieve this objective, we choose the fixed basis sets of 4 and 7 surrogate products with saturation concentrations $\left(1,10,100\right.$ and $\left.1000 \mu \mathrm{g} \mathrm{m}^{-3}\right)$ and $(0.01,0.1,1$, $10,100,1000$ and $10000 \mu \mathrm{g} \mathrm{m}^{-3}$ ), respectively. Using these basis sets, we optimize the objective function in Eq. (2) to fit the measured AMFs for five cases: 1) Low $\mathrm{NO}_{\mathrm{x}}$, dark, and dry conditions, 2) Low $\mathrm{NO}_{\mathrm{x}}, \mathrm{UV}$, and dry conditions, 3) Low $\mathrm{NO}_{\mathrm{x}}$, dark, and high $\mathrm{RH}$ conditions 4) High $\mathrm{NO}_{\mathrm{x}}$, dark, and dry conditions 5) High $\mathrm{NO}_{\mathrm{x}}, \mathrm{UV}$, and dry conditions. In all the above cases, temperature was variable. For all five cases, the enthalpies of vaporization $\left(\Delta H_{\text {evap }}\right)$ were obtained from the temperature dependence of the measured AMFs. The results are summarized in Table 3. The predicted AMFs are compared to the available measurements in Fig. 4. The errors are in the order of $15-20 \%$ that is similar to the experimental errors of typical smog chamber experiments (Pathak et al., 2007). This agreement indicates that the proposed parameterizations reproduce adequately both the older and newer measurements from different studies. The performance of the both the 4- and 7-product basis set parameterizations is similar for practically all data points. The good performance of the parameterization at the different temperatures suggests that our simplifications with the use of one effective vaporization enthalpy and temperature independent stoichiometric coefficients are reasonable approximations of the real behavior of the system.

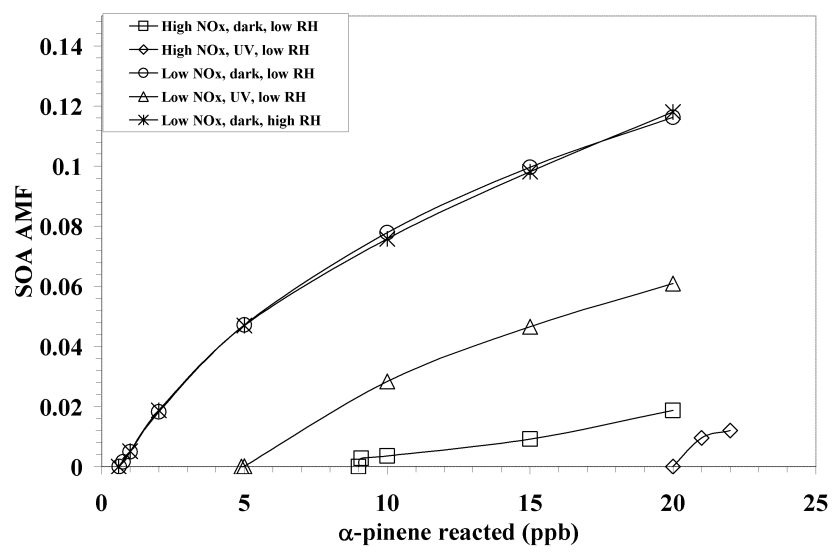

Fig. 6. Predicted SOA AMF by the proposed 7-product parameterization for various conditions as a function of $\alpha$-pinene reacted at different conditions at $25^{\circ} \mathrm{C}$.

Comparison of the stoichiometric coefficients for the low and high $\mathrm{NO}_{\mathrm{x}}$, dry, dark cases suggests that three of them (compounds 5-7) are very similar to each other, while the other four (compounds 1-4) are quite different. The much higher yields of the low volatility products for the low $\mathrm{NO}_{\mathrm{x}}$ case result in a much higher AMF at low organic aerosol levels (less than $10 \mu \mathrm{g} \mathrm{m}^{-3}$ ) where the high volatility components play a negligible role. In this cases, the yields of the components 5-7 in the high $\mathrm{NO}_{\mathrm{x}}$ case are not wellconstrained because there are almost no experiments available where these components are a major fraction of the observed SOA. So the similarity in their yields may be real or may be just a numerical coincidence. The opposite behavior is observed with the low $\mathrm{NO}_{\mathrm{x}}$ dry and wet regimes. In this case the low volatility products have similar yields but the high volatility products have different ones. This results in similar behavior in the relevant low concentration regime but different AMFs at the higher concentration range.

The error of the proposed expressions for the corresponding parts of the full dataset is lower than that of the $\mathrm{HM}$, $\mathrm{GF}$, and $\mathrm{CR}$ parameterizations in the regime (low $\mathrm{NO}_{\mathrm{x}}$, low $\mathrm{RH}$, dark) for which their parameters were estimated (Table 3). Applications of these older parameterizations in the other regimes results in even larger discrepancies with the available measurements.

\section{Predicted SOA formation from $\alpha$-pinene $/ \mathrm{O}_{3}$}

All existing older parameterizations predict that there would be no SOA formation if $\alpha$-pinene concentrations were less than $3.5 \mathrm{ppb}$ in dark, low $\mathrm{NO}_{\mathrm{x}}$ and dry conditions (Fig. 5). However, the proposed 7 product parameterization predicts that a-pinene SOA formation should start after the consumption of approximately $1 \mathrm{ppb}$ of $\alpha$-pinene under the same conditions. The formation of a-pinene SOA at these lower levels 


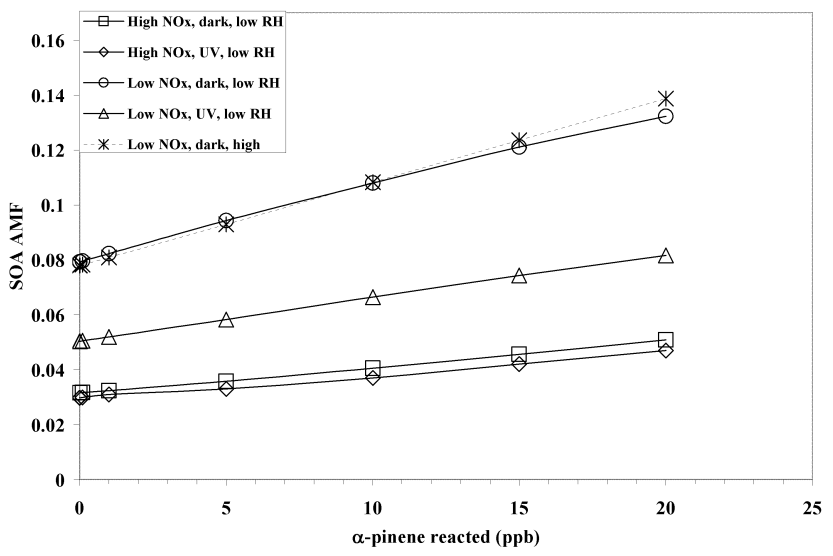

Fig. 7. Predicted SOA AMF by the 7-product parameterizations for $5 \mu \mathrm{g} \mathrm{m}^{-3}$ of pre-existing organic aerosol as a function of reacted $\alpha$-pinene at different conditions at $25^{\circ} \mathrm{C}$.

of reacted a-pinene has been observed by Pathak et al. (2007) adding support to the existence of products with much lower saturation concentrations than those used in the older parameterizations. In general, the proposed parameterization for these conditions predicts higher AMFs than the older expressions for low reacted a-pinene concentrations (or equivalently organic aerosol levels lower than $3 \mu \mathrm{g} \mathrm{m}^{-3}$ ).

A comparison of the predictions of the 5 proposed parameterizations is shown in Fig. 6. For a system with no preexisting organic aerosol approximately $1 \mathrm{ppb}$ of $\alpha$-pinene is needed to react with ozone in the low $\mathrm{NO}_{\mathrm{x}}$ dark case to saturate the gas phase with semivolatile compounds and to start the SOA formation. The threshold increases to $5 \mathrm{ppb}$ in the presence of sunlight, and 9-20 ppb in the high $\mathrm{NO}_{\mathrm{x}}$ case. The predicted $\mathrm{AMF}$ is quite variable varying from zero to 0.12 with the presence of $\mathrm{NO}_{\mathrm{x}}$ and UV reducing the predicted AMF. Nevertheless, these calculations while applicable to the smog chamber do not represent realistic atmospheric conditions where there is always some background preexisting organic aerosol.

For a more realistic case we assume that there is $5 \mu \mathrm{g} \mathrm{m}^{-3}$ preexisting non-volatile organic aerosol of mean molecular weight of $150 \mathrm{~g} \mathrm{~mol}^{-1}$ and that the a-pinene SOA can form with it a pseudo-ideal solution. In this case there is no threshold for the formation of SOA; reaction of even a small amount of $\alpha$-pinene results in the formation of SOA (Fig. 7). For $\alpha$-pinene concentrations of 0.1 to $10 \mathrm{ppb}$, the predicted corresponding SOA mass fractions vary from 0.08 to 0.13 at $25^{\circ} \mathrm{C}$ in low $\mathrm{NO}_{\mathrm{x}}$, dark and low $\mathrm{RH}$ conditions. The AMF in this presence of organic aerosol varies of a relatively narrow range $(0.1 \pm 25 \%)$ for this case. Similar AMFs were predicted for higher RH. In the presence of high $\mathrm{NO}_{\mathrm{x}}$ and UV, predicted AMFs are in the range of 0.03 to 0.06 covering once more a relatively narrow range of values.

In the atmosphere, the background organic aerosol concentrations usually range from approximately 1 to

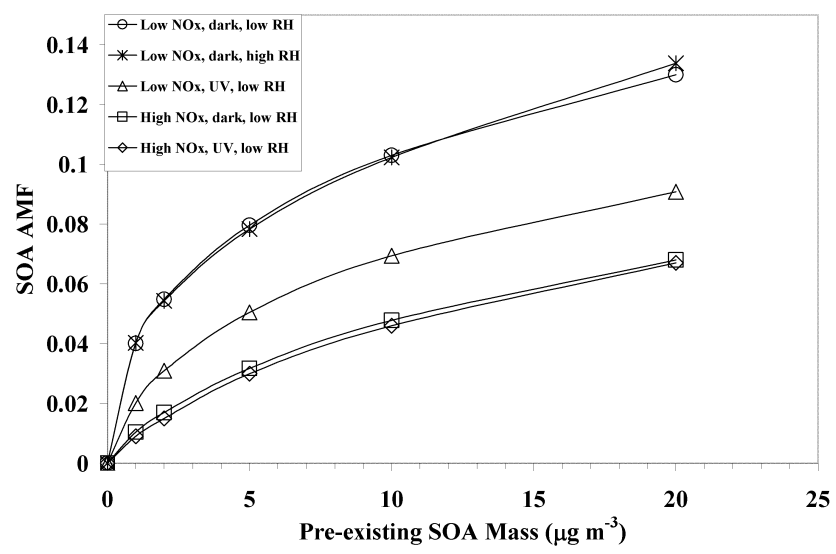

Fig. 8. Predicted SOA AMF by the 7-product parameterizations for $0.1 \mathrm{ppb}$ of reacted $\alpha$-pinene as a function of preexisting organic aerosol concentration at different conditions at $25^{\circ} \mathrm{C}$.

$20 \mu \mathrm{g} \mathrm{m}^{-3}$. The predicted AMFs at $25^{\circ} \mathrm{C}$ range from 0.01 to 0.13 depending on the atmospheric conditions (Fig. 8). The SOA concentration is predicted to be more sensitive to the concentration of organic aerosol participating in the formation of the organic solution than to the reacted $\alpha$-pinene concentration.

\section{Summary and conclusions}

Smog chamber results from a collection of different chambers and representing a wide variety of reaction conditions (low/high $\mathrm{NO}_{\mathrm{x}}$, dark/UV light, dry/humid, low/high temperatures) are used to derive a new set of parameterizations of the SOA formed during $\alpha$-pinene ozonolysis. The basis set of saturation concentrations in the range of $10^{-2}$ to $10^{4} \mu \mathrm{g} \mathrm{m}^{-3}$ is used to fit the measurements from all experiments for: (a) low $\mathrm{NO}_{\mathrm{x}}$, dark, and dry conditions, (b) low $\mathrm{NO}_{\mathrm{x}}, \mathrm{UV}$, and dry conditions, (c) low $\mathrm{NO}_{\mathrm{x}}$, dark, and high $\mathrm{RH}$ conditions, (d) high $\mathrm{NO}_{\mathrm{x}}$, dark, and dry conditions, and (e) high $\mathrm{NO}_{\mathrm{x}}$, UV, and dry conditions. The proposed 4 and 7-product $\alpha$-pinene SOA parameterizations were able to reproduce all the measurements included in this study within experimental error $(\sim 15 \%)$. The set of parameterizations can be used in chemical transport models, using the appropriate set of parameters for the corresponding atmospheric conditions.

Acknowledgement. Financial support by USEPA (STAR-831081) is gratefully acknowledged.

Edited by: S. Martin 


\section{References}

Andreae, M. O. and Crutzen, P. J.: Atmospheric aerosols: biogeochemical sources and role in atmospheric chemistry, Science, 276, 1052-1058, 1997.

Cocker, D. R., Clegg, S. L., Flagan, R. C., and Seinfeld, J. H.: The effect of water on gas-particle partitioning of secondary organic aerosol. Part I: $\alpha$-pinene/ozone system, Atmos. Environ., 35, 6049-6072, 2001.

Czoschke, N. M. and Jang, M.: Acidity effects on the formation of a-pinene SOA in the presence of inorganic seed, Atmos. Environ, 40, 4370-4380, 2006.

de Gouw, J. A., Middlebrook, A. M., Warneke, C., Goldan, P. D., Kuster, W. C., Roberts, J. M., Fehsenfeld, F. C., Worsnop, D. R., Canagaratna, M. R., Pszenny, A. A. P., Keene, W. C., Marchewka, M., Bertman S. B., and Bates, T. S.: Budget of organic carbon in a polluted atmosphere: Results from the New England Air Quality Study in 2002, J. Geophys. Res., 110, D16305, doi:10.1029/2004JD005623, 2005.

Donahue, N. M., Robinson, A. L., Stanier, C. O., Pandis, S. N.: Coupled partitioning, dilution, and chemical aging of semivolatile organics, Environ. Sci. Technol., 40, 2635-2643, 2006.

Fick, J., Pommer, L., Nilsson, C., and Andersson, B.: Effect of $\mathrm{OH}$ radicals, relative humidity, and time on the composition of the products formed in the ozonolysis of alpha-pinene, Atmos. Environ., 37, 4087-4096, 2003.

Gao, S., Ng, N. L., Keywood, M., Varutbankgkul, V., Bahreini, R., Nenes, A., He, J., Yoo, K. Y., Beauchamp, J. L., Hodyss, R. P., Flagan, R. C., and Seinfeld, J. H.: Particle phase acidity and oligomer formation in secondary organic aerosol, Environ. Sci. Technol., 38, 6582-6589, 2004.

Griffin, R. J., Cocker, D. R., and Seinfeld, J. H.: Estimate of global atmospheric organic aerosol from oxidation of biogenic hydrocarbons, Geophys. Res. Lett., 26, 2721-2724, 1999a.

Griffin, R. J., Cocker, D. R., Flagan, R. C., and Seinfeld, J. H.: Organic aerosol formation from the oxidation of biogenic hydrocarbons, J. Geophys. Res., 104, 3555-3567, 1999 b.

Guenther A., Hewitt, C. N., Erickson, D., Fall, R., Geron, C., Graedel, T., Harley, P., Klinger, L., Lerdau, M., Mckay, W.A., Pierce, T., Scholes, B., Steinbrecher, R., Tallamraju, R., Taylor, J., and Zimmerman, P.: A global-model of natural volatile organic-compound emissions, J. Geophys. Res., 100, 88738892, 1995.

Heald C. L., Jacob, D. J., Park, R. J., Russell, L. M., Huebert B. J., Seinfeld, J. H., Liao, H., and Weber, R. J.: A large organic aerosol source in the free troposphere is missing from current models, Geophys. Res. Lett., 32, L18809, doi:10.1029/2005GL023831, 2005.

Hoffmann, T., Odum, J. R., Bowman, F. A., Collins, D., Klockow, D., Flagan, R. C., and Seinfeld, J. H.: Formation of organic aerosol from the oxidation of biogenic hydrocarbons, J. Atmos. Chem., 26, 189-222, 1997.

Hoppel, W, Fitzgerald, J., and Frick, G.: Particle formation and growth from ozonolysis of alpha-pinene, J. Geophys. Res., 106, 27 603-27 618, 2001.

Iinuma Y., Boge, O., Gnauk, T., and Hermann, H.: Aerosolchamber study of the $\alpha$-pinene $/ \mathrm{O}_{3}$ reaction: influence of particle acidity on aerosol yields and products, Atmos. Environ., 38, 761-773, 2004.
Jang, M. and Kamens, R. M.: A thermodynamic approach for modeling partitioning of semivolatile organic compounds on atmospheric particulate matter: Humidity effects, Environ. Sci. Technol., 32, 1237-1243, 1998.

Koo, B. Y., Ansari, A. S., and Pandis, S. N.: Integrated approaches to modeling the organic and inorganic atmospheric aerosol components, Atmos. Environ., 37, 4757-4768, 2003.

Lee, A., Goldstein, A. H., Keywood, M. D., Gao, S., Varutbangkul, V., Bahreini, R., Ng, N. L., Flagan, R. C., and Seinfeld, J. H.: Gas-phase products and secondary organic aerosol yields from the ozonolysis of ten different terpenes, J. Geophys. Res., 111, D07302, doi:10.1029/2005JD006437, 2006.

Ng, N. L., Kroll, J. H., Keywood, M. D., Bahreini, R., Varutbangkul, V., Flagan, R. C., Seinfeld, J. H., Lee, A., and Goldstein, A. H.: Contribution of first- versus second-generation products to secondary organic aerosols formed in the oxidation of biogenic hydrocarbons, Environ. Sci. Technol., 40, 2283-2297, 2006.

Offenberg, J. H., Kleindienst, T. E., Jaoui, M., Lewandowski, M., and Edney, E. O.: Thermal properties of secondary organic aerosols, Geophys. Res. Lett., 33, L03816, doi:10.1029/2005GL024623, 2006.

Odum, J. R., Hoffmann, T., Bowman, F., Collins, D., Flagan, R. C., and Seinfeld, J. H.: Gas/particle partitioning and secondary organic aerosol yields, Environ. Sci. Technol., 30, 2580-2585, 1996.

Pankow, J. F.: An absorption model of gas/particle partitioning of organic compounds in the atmosphere, Atmos. Environ., 28, 185-188, 1994a.

Pankow, J. F.: An absorption-model of the gas aerosol partitioning involved in the formation of secondary organic aerosol, Atmos. Environ., 28, 189-193, 1994b.

Pankow, J. F., Seinfeld, J. H., and Asher, W. E.: Modeling the formation of secondary organic aerosol. 1. Application of theoretical principles to measurements obtained in the alphapinene/, beta- pinene/, sabinene/, Delta(3)-carene/, and cyclohexene/ozone systems, Environ. Sci. Technol., 35, 1164-1172, 2001.

Pathak, R. K., Stanier, C. O., Donahue, N. M., and Pandis, S. N.: Ozonolysis of $\alpha$-pinene at atmospherically relevant concentrations: Temperature dependence of aerosol mass fractions (yields), J. Geophys. Res., 112, D03201, doi:10.1029/2006JD007436, 2007.

Presto, A. A., Huff-Hartz, K. E., and Donahue, N. M.: Secondary organic aerosol production from terpene ozonolysis: 1. Effect of UV radiation, Environ. Sci. Technol., 39, 7036-7045, $2005 \mathrm{a}$.

Presto, A. A., Huff-Hartz, K. E., and Donahue, N. M.: Secondary organic aerosol production from terpene ozonolysis: 2. Effect of $\mathrm{NO}_{\mathrm{x}}$ concentration, Environ. Sci. Technol., 39, 7046-7054, $2005 b$.

Presto, A. A. and Donahue, N. M.: Investigation of $\alpha$-pinene + ozone secondary organic aerosol formation at low total aerosol mass, Environ. Sci. Technol., 40, 3536-3543, 2006.

Pun, B. K., Griffin, R. J., Seigneur, C., and Seinfeld, J. H.: Secondary organic aerosol - 2. Thermodynamic model for gas/particle partitioning of molecular constituents, J. Geophys. Res., 107, 4333, doi:2001D000542, 2002.

Pun, B. K., Wu, S. Y., Seigneur, C., Seinfeld, J. H., Griffin, R. J., and Pandis, S. N.: Uncertainties in modeling sec- 
ondary organic aerosols: Three-dimensional modeling studies in Nashville/Western Tennessee, Environ. Sci. Technol., 37, 36473661, 2003.

Saathoff, H., Linke, C., Naumann, K. H., Wagner, R., Weingartner, E., Schurath, U.: Temperature dependence of the yield of secondary organic aerosol from the ozonolysis of $\alpha$-pinene and limonene, Abstracts of European Aerosol Conference, S151S152, 2004.

Seinfeld, J. H., Erdakos, G. B., and Asher, W. E.: Modeling the formation of secondary organic aerosol (SOA). 2. The predicted effects of relative humidity on aerosol formation in the alpha-pinene-, beta-pinene-, sabinene-, Delta(3)-Carene-, and cyclohexene-ozone systems, Environ. Sci. Technol., 35, 18061817, 2001.

Seinfeld, J. H. and Pankow, J. F.: Organic atmospheric particulate material, Ann. Rev. Phys. Chem., 54, 121-140, 2003.

Stanier, C. O., Pathak, R. K., and Pandis, S. N.: Measurements of the volatility of aerosols from $\alpha$-pinene ozonolysis, Environ. Sci. Tech., 41, 2756-2763, 2007.

Strader, R., Gurciullo, C., Pandis, S. N., Kumar N., and Lurmann, F. W.: Final Report STI-997510-1822, Coordinating Research Council, Alpharetta, GA, 1998, NTIS PB99-128738, 1999a.

Strader, R., Lurmann, F., and Pandis, S. N.: Evaluation of secondary organic aerosol formation in winter, Atmos. Environ., 33, 48494863, 1999 b.

Takegawa, N., Miyakawa, T., Kondo, Y., Blake, D. R., Kanaya, Y., Koike, M., Fukuda, M., Komazaki, Y., Miyazaki, Y., Shimono, A., and Takeuchi, T.: Evolution of submicron organic aerosol in polluted air exported from Tokyo, Geophys. Res. Lett., 33, L15814, doi:10.1029/2006GL025815, 2006.
Takekawa, H., Minoura, H., and Yamazaki, S.: Temperature dependence of secondary organic aerosol formation by photo-oxidation of hydrocarbons, Atmos. Environ., 37, 3413-3424, 2003.

Tsigaridis, K. and Kanakidou, M.: Global modeling of secondary organic aerosol in the troposphere: a sensitivity analysis, Atmos. Chem. Phys., 3, 1849-1869, 2003, http://www.atmos-chem-phys.net/3/1849/2003/.

Volkamer, R., Jimenez, J. L., San Martini, F., Dzepina, K., Zhang, Q., Salcedo, D., Molina, L. T., Worsnop, D. R., and Molina, M. J.: Secondary organic aerosol formation from anthropogenic air pollution: rapid and higher than expected, Geophys. Res. Lett., 33, L17811, doi:10.1029/2006GL026899, 2006.

Winterhalter, R., Van Dingenen, R., Larsen, B. R., Jensen, N. R., and Hjorth, J.: LC-MS analysis of aerosol particles from the oxidation of $\alpha$-pinene by ozone and $\mathrm{OH}$-radicals, Atmos. Chem. Phys. Discuss., 3, 1-39, 2003, http://www.atmos-chem-phys-discuss.net/3/1/2003/.

Yu, J., Cocker, D. R., Griffin, R. J., Flagan, R. C., and Seinfeld J. H.: Gas-phase ozone oxidation of monoterpenes: Gaseous and particulate products, J. Atmos. Chem., 34, 207-258, 1999.

Zhang, J., Huff-Hartz, K. E., Pandis, S. N., and Donahue, N. M: Secondary organic aerosol formation from limonene ozonolysis: Homogeneous and heterogeneous influences as a function of $\mathrm{NO}_{\mathrm{x}}$, J. Phys. Chem. A., 110, 11 053-11 063, 2006. 